\title{
Short Communication: The study of suweg (Amorphophallus paeoniifolius) and other undergrowth species in teak plantation forest of Temengeng, Blora, Indonesia
}

\author{
SYAMSUL HIDAYAT \\ Center for Plant Conservation Botanic Gardens (Bogor Botanic Gardens), Indonesian Institute of Sciences. Jl. Ir. H. Juanda 13, Bogor 16122, West Java, \\ Indonesia. Tel./fax.: +62-251-8311362, 8336871, "email: hidayatkbri@yahoo.com
}

Manuscript received: 24 September 2018. Revision accepted: 1 December 2018.

\begin{abstract}
Hidayat S. 2019. The study of suweg (Amorphophallus paeoniifolius) and other undergrowth species in teak plantation forest of Temengeng, Blora, Indonesia. Biodiversitas 20: 37-42. Suweg (Amorphophallus paeoniifolius (Dennst.) Nicolson) is one of the potential sources of food plants that are often found growing wild in farmers' gardens or fields. In the teak plantation forest of Cepu, precisely in Temengeng village, there are many suwegs growing among the old and big teak trees. To find out the potential and range of habitat where suweg grows, especially in teak plantation forest, ten observation plots were made using purposive sampling method, each measuring $10 \times 10 \mathrm{~m}^{2}$. Overall, 17 adults and 30 young individuals of suweg were found. In addition to teak, 43 wild plant species were identified alongside suweg, from various habits, namely herb, liana, shrub, epiphyte, and tree. Herbs were the most common plants growing around suweg, especially from the families of Fabaceae, Compositae, and Zingiberaceae. The species that were almost always found together in the suweg plots were Tetrastigma lanceolarium (Roxb.) Planch. and Thespesia lampas (Cav.) Dalzell, but in quantity, Costus spiralis (Jacq.) Roscoe was more abundant than the other two species, although it was only found in four sampling plots. The results of this study also showed that there was no association between suweg and certain plants; this was supported by the low similarity index among plots.
\end{abstract}

Keywords: Habitat, potential, suweg, teak plantation

\section{INTRODUCTION}

Temengeng is a village in the middle of teak plantation forest. It is located in Sambong Sub-district, Blora District, Central Java Province. Most of the population live as farmers and laborers on teak plantations. Teak plantation areas around this village are included in the forest management area of Perhutani, namely in the RPH (the smallest sub-unit of forest management area) of Temengeng, BKPH (the sub-unit of forest management area) of Pasar Sore, KPH (the unit of forest management area) of Cepu. Part of the area, i.e. the Wana Wisata Gubug Payung, where there are teak trees that are hundreds of years old, is allocated for reformation program, while some other areas still function as production forests.

In the middle of this old teak tree, there are lots of undergrowth in the form of wild herbs and shrubs. Groups of undergrowth in plantations are usually seen as weeds, but when viewed from the aspect of economic potential in the future, undergrowth plants can provide choice values. According to Kunarso and Azwar (2013), the value of choice is the connection with the potential to provide benefits in the future, so the extinction of undergrowth means a loss for human welfare in the future. One of the wild plants that can be found in the teak plantation area in Temengeng, is suweg or elephant foot yam, or Amorphophallus paeoniifolius (Dennst. Nicolson). The plant has anti-bacterial activity in its tuber and peels extracts. This tuber accounts for several pharmacological effects (Kadali et al. 2016). Basu et al. (2014) say that consumption of this tuber for its sufficient amount of essential micronutrients can be considered as nutritionally valuable and healthy. This tuber contains $18.0 \%$ starch, 1$5 \%$ protein and up to $2 \%$ fat. Suweg's leaf contains $2-3 \%$ protein, 3\% carbohydrates and $4-7 \%$ crude fiber. The tubers and leaves are quite acrid due to their high content of oxalates. Acridity is usually removed by boiling for a fairly long time (Kumar et al. 2015).

Suweg belongs to the family of Araceae. It is a crop of South East Asian origin. It grows wild in the Philippines, Malaysia, Indonesia and other South East Asian countries (Madhurima et al. 2012). Indonesia and Thailand could be the centers of diversity of A. paeoniifolius, but the corms of the species are commercially traded in the local markets of India, and are less frequent in those of Indonesia (Santosa et al. 2017). In Indonesia particularly in Java island, two common names for this species are walur and suweg. Suweg is popular in Java for its edible tubers. According to Yuzammi et al. (2017), the species has a long history of cultivation and has probably escaped and become weedy in many areas in its present-day distribution. The constantly changing people's lifestyle and the increasing presence of a variety of modern foods cause the suweg to be forgotten. This plant is currently categorized as least concern on 
IUCN red list ver 3.1 because it has very large geographic range, ruderal strategy, low habitat specificity, and it is widely cultivated throughout its range (Romand-Monnier 2013).

The purpose of this study was to determine the condition of the population and habitat of suweg in Temengeng teak plantation forest. It is expected that the results of this study can be used as one of the basic information in the management of teak plantation forest areas in the future because teak plantation forests in Temengeng can also produce other potentials of the undergrowth plants, especially suweg for the welfare of the people in the surrounding villages.

\section{MATERIALS AND METHODS}

\section{Research site}

This research has been conducted in the teak plantation forest area, RPH of Temengeng, BKPH of Pasar Sore, KPH of Cepu, precisely in Temengeng Village, Sambong Subdistrict, Blora District, Central Java Province, Indonesia. This area can be reached by vehicles in about 30 minutes from the center of Cepu City to the northwest; it is about 25 km away (Figure 1).

\section{Data collection}

Sampling was done using a purposive sampling method. A total of 10 sampling plots, each measuring $10 \mathrm{x}$ $10 \mathrm{~m}^{2}$, were made in locations where suweg plant was found. In each sampling plot, the number of suweg plants, both young and adult, was recorded. Other plants found in each plot were also identified directly in the field and the names were confirmed later based on the accepted version of the plant list. The environmental factors were measured using related tools; temperature and humidity were measured with a thermohygrometer, sunlight intensity with a lux meter, soil acidity $(\mathrm{pH})$ with a soil $\mathrm{pH}$ tester, topography with a Shunto clinometer. The position and altitude of sites were determined using Garmin GPS. The percent of canopy cover and forest floor cover in each plot were calculated manually using small boxes and meter tapes.

\section{Data analyses}

The data obtained were tabulated in the Exel program. The number of suweg individuals and the frequency of each supporting plant species were calculated. The dominance of plant species and families were estimated qualitatively based on the percentage of area cover in each plot. Meanwhile, to obtain information on differences in plant species composition among suweg habitats, species similarity index (IS) was calculated using the following formula (Diserud and Odegaard 2007).

$$
\text { IS }=(2 \mathrm{w} / \mathrm{a}+\mathrm{b}) \times 100 \%
$$

Where:

$\mathrm{w}$ : number of species found in both sites

a : number of species found in site a

b : number of species found in site $b$

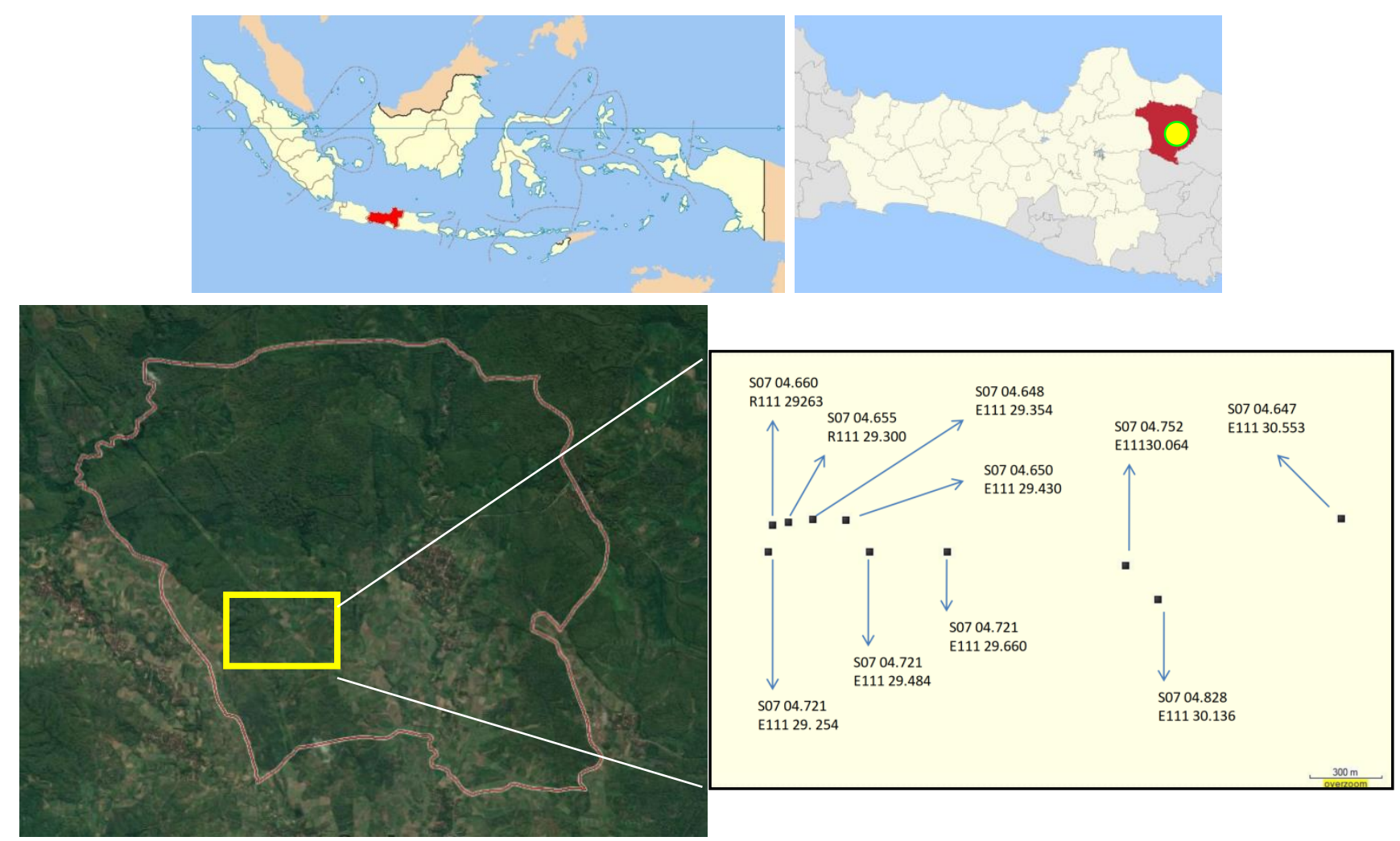

Figure 1. Locations of suweg observation plots in Temengeng Village, Sambong Sub-district, Blora District, Central Java Province, Indonesia 

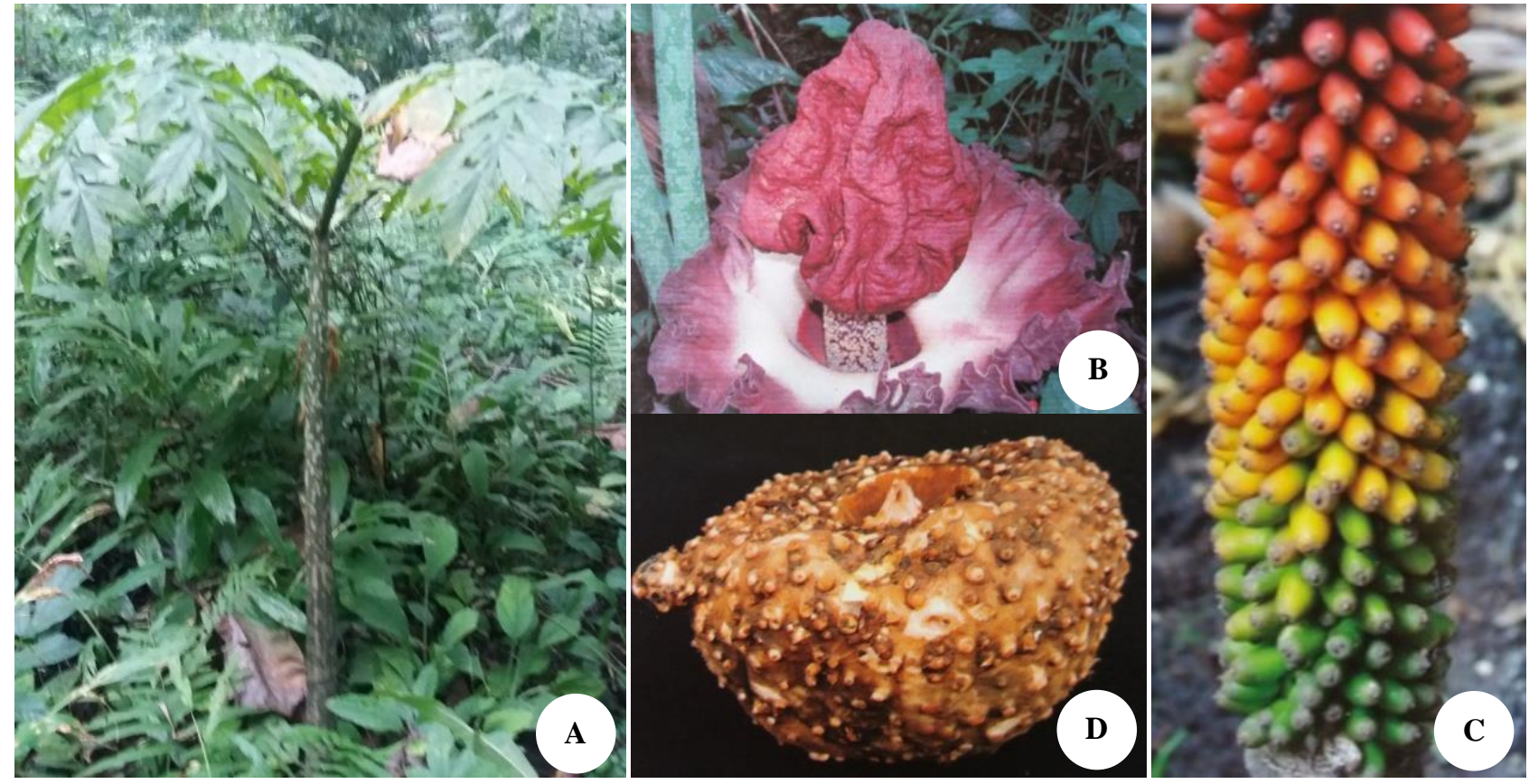

Figure 2. Suweg plant (Amorphophallus paeoniifolius). A. Habit, B. Inflorescence/flower, C. Seeds, D. Tuber (Photo by (A): Syamsul; (B,C,D): Yuzammi)

\section{RESULTS AND DISCUSSION}

\section{Suweg population}

Wild populations of $A$. paeoniifolius are mostly clumped along the forest edge, as well as on abandoned land, riverbanks or the edges of conservation forests. The species is also cultivated as a mixed crop in the fields of banana, ginger, groundnuts (Singh and Wadhwa 2014). In Lombok Island, many elephant foot yam seedlings grow around a tree base and in the cavity of dead branches of trees. It is probable that birds feed on the sweet pulp of mature berries and drop the seeds, facilitating shortdistance dispersal (Santosa et al. 2017).

In general, in Indonesia there are two varieties of $A$. paeoniifolius; the first one having slippery trunks is known as suweg and the second having rough trunks is known as walur. In this study, special observations were addressed to Suweg, which has been widely consumed in several regions. The tubers can usually be eaten with certain treatments.

Suweg is a robust herbaceous plant, $1.0-1.5 \mathrm{~m}$ tall. Large dissected tripartite leaves constitute the luxuriant outspreading crown-like foliage, borne on a fairly thick single upright "stem". The aerial "pseudostem" which is round with a characteristic of irregular blotches is botanically a leaf petiole. It flowers once in 1-3 years. Inflorescence consists of a bell-shaped spathe surrounding a central yellow spadix and is borne on a very short stalk. It appears almost at ground level. (Kumar et al. 2015). Fruit is produced in spikes. Individual fruits are ellipsoid to globular, orange to red.

Of the ten plots surveyed, a total of 17 adults or 170 individuals/ha and 30 young individuals or 300 individuals/ha were recorded (Table 1).

\section{Other plants in suweg habitat}

From all plots, 43 wild plant species that lived together with suweg were found, composed of various habits, namely herb, liana, shrub, and trees. Herbs are the most common plants growing around suweg, represented by 15 species, both annual or perennial herbs. Shrubs consisted of 14 species and liana 6 species. There were not many tree species found, because according to Healey and Gara (2003) the development of teak plantation reduces the diversity of native trees. Fabaceae was the family most commonly found, consisting of 8 species. This is also similar to the results of Nikmah (2016) research in Brojonegoro teak forests that the Fabaceae family or legumes are the most common. Fabaceae is a family of plants that can help the fertility of the soil because of its symbiosis with Rhizobium which can fix nitrogen $(\mathrm{N})$. Nitrogen and potassium $(\mathrm{K})$ are important for increasing corm yield of Amorphophallus species (Santosa et al. 2015). After Fabaceae, the second most abundant family was Lamiaceae consisting of 4 species, then followed by Compositae and Zingiberaceae, each consisting of 3 species. Meanwhile, the plants almost always found growing on the suweg plots were Tetrastigma lanceolarium and Thespesia lampas; both species were found in eight plots of ten sampling plots. But Costus spiralis qualitatively appeared to be more abundant than the two species, although it was only found in seven sampling plots. Quantitatively, the number of $C$. spiralis individuals was not calculated, but qualitatively the average cover was $70-80 \%$ in four plots and under $50 \%$ in the other three plots. On the other hand, T. lanceolarium and T. lampas dominated only $10-20 \%$ of the plots, still less invasive than Chromolaena odorata and Imperata cylindrica. C. odorata was also found as the dominant shade plant in the A paeoniifolius research plot conducted by Mulyati et al. (2017). The dominant species in each sampling plot are shown in Table 2. 
Table 1. The number of individual Suweg plants in each sampling plot

\begin{tabular}{lccccl}
\hline \multirow{2}{*}{ Plot number } & \multicolumn{2}{c}{ Number of individual suweg } & \multicolumn{2}{c}{ Location information } \\
\cline { 2 - 6 } & Adult & Young & Altitude (m asl) & Latitude \& longitude & Topo \\
\hline I & 1 & 1 & 134 & S 07 04 660, E 110 29 263 & slope, 50\% \\
II & 2 & 5 & 106 & S 07 04 655, E 110 29 300 & slope, 50\% \\
III & 3 & 2 & 100 & S 07 04 648, E 110 29 354 & flat \\
IV & 3 & 2 & 110 & S 07 04 650, E 110 29 430 & flat \\
V & 3 & 2 & 100 & S 07 04 721, E 110 29 254 & flat \\
VI & 2 & 1 & 100 & S 07 04 721, E 110 29 484 & slope, 50\% \\
VII & 1 & 5 & 100 & S 07 04 721, E 110 29 660 & flat \\
VIII & 1 & 6 & S 07 04 752, E 110 30 064 & flat \\
IX & 1 & 5 & 109 & S 07 04 828, E 110 30 136 & flat \\
X & 0 & 1 & 110 & S 07 04 647, E 110 30 553 & flat \\
\hline
\end{tabular}

Table 2. Dominant species in each sampling plot

\begin{tabular}{llcl}
\hline Plot & Dominant species & Plot cover $(\boldsymbol{\%})$ & Location \\
\hline I & Cyclosorus terminans (J. Sm. ex Hook.) K.H. Shing & 50 & Waterside \\
II & Paspalum conjugatum P.J.Bergius & 60 & Waterside \\
III & Costus spiralis (Jacq.) Roscoe & 70 & Waterside \\
IV & Costus spiralis (Jacq.) Roscoe & 80 & Waterside \\
V & Ficus montana Burm.f. & 50 & Edge of the path \\
VI & Costus spiralis (Jacq.) Roscoe & 75 & Waterside \\
VII & Costus spiralis (Jacq.) Roscoe & 75 & Waterside \\
VIII & Chromolaena odorata (L.) R.M.King \& H.Rob. & 75 & Waterside \\
IX & Caesalpinia sappan L. & 50 & Big road edge \\
X & Imperata cylindrica (L.) Raeusch. & 90 & Edge of the path \\
\hline
\end{tabular}

Table 3. Value of similarity index for non-suweg species between pair of plots

\begin{tabular}{|c|c|c|c|c|c|c|c|c|c|c|}
\hline Plot & I & II & III & IV & $\mathbf{V}$ & VI & VII & VIII & IX & $\mathbf{X}$ \\
\hline I & & 0.40 & 0.62 & 0.52 & 0.42 & 0.57 & 0.5 & 0.23 & 0 & 0 \\
\hline II & & & 0.46 & 0.48 & 0.48 & 0.59 & 0.5 & 0.32 & 0.17 & 0.13 \\
\hline III & & & & 0.96 & 0.77 & 0.55 & 0.74 & 0.38 & 0.08 & 0 \\
\hline IV & & & & & 0.74 & 0.56 & 0.69 & 0.37 & 0 & 0 \\
\hline V & & & & & & 0.56 & 0.8 & 0.31 & 0.08 & 0.13 \\
\hline VI & & & & & & & 0.33 & 0 & 0 & 0.33 \\
\hline VII & & & & & & & & 0.48 & 0.15 & 0.13 \\
\hline VIII & & & & & & & & & 0.31 & 0.13 \\
\hline IX & & & & & & & & & & 0.38 \\
\hline$X$ & & & & & & & & & & \\
\hline
\end{tabular}

Table 4. The average value of local environmental factors per plot

\begin{tabular}{lccccc}
\hline Plot & $\begin{array}{c}\text { Temp. } \\
\left({ }^{\circ} \mathbf{C}\right)\end{array}$ & $\begin{array}{c}\text { Humidity } \\
(\boldsymbol{\%})\end{array}$ & $\begin{array}{c}\text { Sunlight } \\
(\mathbf{l u x})\end{array}$ & $\begin{array}{c}\text { Soil } \\
\mathbf{p H}\end{array}$ & $\begin{array}{c}\text { Canopy } \\
\text { cover }(\boldsymbol{\%})\end{array}$ \\
\hline I & 33.5 & 64 & 226.9 & 6.4 & 60 \\
II & 33.4 & 65.5 & 80 & 6.5 & 60 \\
III & 33.5 & 65.8 & 80 & 6.4 & 50 \\
IV & 33.5 & 65.8 & 80 & 6.4 & 50 \\
V & 33.5 & 65.8 & 80 & 6.4 & 50 \\
VI & 33.4 & 65 & 80 & 6.4 & 40 \\
VII & 33.4 & 65 & 80 & 6.4 & 40 \\
VIII & 33.9 & 61.5 & 238 & 6.2 & 70 \\
IX & 35.5 & 58.5 & 125 & 5.8 & 50 \\
X & 33.9 & 61.5 & 238 & 6.2 & 100 \\
\hline
\end{tabular}

The index Sørensen's similarity index measures similarity between two habitats whose value varies between 0 and 1 . Zero indicates no similarity and 1 indicates maximum similarity (Dubey et al. 2013). The similarity index values (Table 3 ) show that most plots had little species composition similarity from one another. Only one pair had very high similarity index (0.96), namely the third and fourth plots. Most of the plot pairs had similarity index values under 0.5 and even 0 , meaning that undergrowth species composition was different from one plot to another.

The highest value of similarity index (IS) between plots III and IV is presumably caused more by climate and topographic similarity rather than by association between species. Plots III and IV had a similar condition, were located on a flat land and under a large teak tree with a diameter of about $100 \mathrm{~cm}$ and a wide crown. Meanwhile, there were seven pairs of plots having zero values, meaning that the species composition in the two plots was completely different. This shows that there was no specific association between suweg and other plant species.

\section{Environmental factors}

Environment is an important factor that influences the existence of plant species. Suweg grows well in sites not directly exposed to sunlight, but in the shade of various vegetation around it, which can be shrubs or trees. The vegetation plays an important role in the survival of $A$. 
paeoniifolius, because with the presence of vegetation, this plant can be shaded so that climate factors such as temperature, humidity and light intensity are suitable for its growth (Mulyati et al. 2017).

Elephant foot yam grows well in tropical, warm, humid conditions with maximum day-time temperature ranging between $25^{\circ}$ and $35^{\circ} \mathrm{C}$, minimum night-time temperature between $20^{\circ}$ and $25^{\circ} \mathrm{C}$ and annual rainfall between 1000 and $3000 \mathrm{~mm}$ spread over a period of about six to eight months. Singh and Wadhwa (2014) say that the hot and humid climate provides better growth of suweg. Hot and humid climate is required at initial stages of the crop for vigorous growth, whereas dry climates facilitate tuber bulking at later stage (Kumar et al. 2015).

Of the ten sampling plots (Table 4) only one plot had a soil $\mathrm{pH}$ under 6 , i.e. the 9 th plot, but in this plot there were several species of Fabaceae which contributed to soil fertility with its ability to supply nitrogen. Most of the plots had a soil $\mathrm{pH}$ between 6-6.5, so a variety of plants appeared to thrive because, according to Nikmah et al. (2016), in general, plants easily absorb nutrients at $\mathrm{pH}$ close to neutral $\mathrm{pH}$ (pH 6 to 7 ).

\section{Potential of suweg and other herbs}

A. paeoniifolius has long been used as a local staple food in many countries such as the Philippines, Indonesia, Malaysia, Bangladesh, India, China and other Southeastern Asian countries (Sugiyama and Santosa 2008). It is an important economic crop because of its high production potential (50-60 t/ha) and is usually used as vegetable (Gao et al. 2017), and its tubers are rich in nutrients. It is a healthy low-fat food, containing a good source of protein as well as starch (Bais and Mali 2013). Basu et al. (2014) reveal that the tuber of $A$. paeoniifolius has high crude protein, moisture, fiber, ash, vitamins $\mathrm{E}$ and $\mathrm{C}$ content. Besides, the tuber is rich in almost all the essential macro and micro-nutrients. The tuber is interestingly an important source of potassium, calcium and sodium. Moreover, the tuber also lacks the presence of heavy metals like mercury, cadmium, lead and arsenic. Putri et al. (2018) say that extract of elephant foot yam is known to contain flavonoid that is an antioxidant compound and thus has the potential to be utilized as functional food in the form of beverages.

The plant A.paeoniifolius is found to be a potent herbal plant showing diverse activities. The ethanolic extract shows antioxidant and antitumor activities. The leaves found to have antidiarrheal activity (Madhurima et al. 2012). Meanwhile, Singh et al. (2017) suggest that elephant foot yam can be used as a rich and convenient source of peroxidase for various applications including wastewater remediation. Peroxidases are used for the bioremediation of wastewater contaminated with hazardous aromatic compounds.

In India $A$. paeoniifolius is also cultivated as an intercrop along with turmeric and under coconuts or bananas (Ravi et al. 2011). In Indonesia, on the other hand, suweg is an underutilized crop that commonly grows under shade (Santosa et al. 2015) but in Kuningan District suweg is one of forest food crops in agroforestry systems (Nurlaila et al. 2018) and its steamed corms are still used in some districts of Java (Sugiyama and Santosa 2008).

In the environmental conditions as above, other plants that have the economic potential were found to be quite abundant, namely Tacca palmata, Zingiber zerumbet and some potential medicinal plants such as Arcangelisia flava and Caesalpinia sappan. Tacca palmata has high carbohydrates, and contains chemical compounds for medication, potentially useful lead compounds for anticancer properties (Trimanto and Hapsari 2016). Various ginger spices of the Zingiberaceae family are widely used as spices, flavoring agents, and medicines in Southeast Asia because of their unique flavor as well as their medicinal properties. One of them is Zingiber zerumbet, whose cones are also used as an ornamental in gardening, and the milky juice obtained from the cones is famously used as a shampoo (Yob et al. 2011). Arcangelisisa flava has been used as a traditional medicine in many regions of Indonesia for treating various diseases (Lovin et al. 2012). The water extract of $A$. flava can be utilized as a safe natural food additive, especially in the production of palm sugar (Heryani and Nugroho 2015). The wood of Caesalpinia sappan has export quality of natural dye and it has the potential to become a drug for sale in the world market due to its interesting biological effects and vast folklore uses (Mariappan et al. 2014).

\section{ACKNOWLEDGEMENTS}

This research has been carried out in conjunction with the exploration of flora in the Central Java region. The members of the exploration team are a combination of staff from Bogor Botanic Gardens, Purwodadi Botanic Gardens, and Boyolali Botanic Gardens. Therefore, I thank the friends who are members of this team, especially the group leader, Dr. Titien Ng. Praptosuwiryo. I thank you also to the head of Perhutani KPH Cepu who gave permission and convenience in carrying out this research. Special thanks to the head of the Temengeng RPH, Sarjono and his staff who have assisted the activities in the field.

\section{REFERENCES}

Bais SS, Mali PY. 2013. Protective effect of A. campanulatus tuber extracts against $\mathrm{H}_{2} \mathrm{O}_{2}$ induced oxidative damage. Int J Green Pharm 7: 111-116.

Basu S, Das M, Sen A, Choudhury UR, Datta G. 2014. Analysis of Complete Nutritional Profile of Amorphophallus campanulatus tuber cultivated in Howrah District of West Bengal, India. Asian J Pharm Clin Res 7 (3): 25-29.

Diserud OH, Ødegaard F. 2007. A multiple-site similarity measure. Biol Lett 3: 20-22.

Dubey VK, Sarkar UK, Pandey A, Lakra WS. 2013. Fish communities and trophic metrics as measures of ecological degradation: A case study in the tributaries of the River Ganga Basin, India. Int J Trop Biol 61 (3): 1351-1363.

Gao Y, Yin S, Wu L, Dai D, Wang H, Liu C, Tang L. 2017. Genetic diversity and structure of wild and cultivated Amorphophallus paeoniifolius populations in southwestern China as revealed by RADseq. Sci Rep7: 14183-14192. 
Healey SP, Gara RI. 2003. The effect of teak (Tectona grandis) plantation on the establishment of native species in an abandoned pasture in Costa Rica. ForEcol Manag 176: 497-507.

Heryani H, Nugroho A. 2015. Study of yellow root (Arcangelisia flava Merr) as a natural food additive with antimicrobial and aciditystabilizing effects in the production process of palm sugar. Procedia Environ Sci 23: 346-350

Kadali VN, Pola SR, Ramesh T, Sandeep BV. 2016. Assessment of antibacterial activity of Amorphophallus paeoniifolius tuber and its peel extracts. Trop Plant Res 3 (1): 172-175.

Kumar RPK, Kolli SK, Suneetha J, Hemanth G 2015. Cultivation of Amorphophallus paeoniifolius (Dennst.) Nicolson (Elephant Foot Yam) in Kovvur Mandal of West Godavari District, Andhra Pradesh India. Int J Curr Res 7 (5): 15549-15553

Kunarso A, Azwar F. 2013. Keragaman jenis tumbuhan bawah pada berbagai tegakan hutan tanaman di Benakat, Sumatera Selatan. JPHT 10 (2): 85-98. [Indonesian]

Lovin ER, Heny Arwati H, Ramadhani RB. 2012. In vitro intraerythrocytic antimalarial activity of akar kuning (Arcangelisia flava (L.) Merr.) stem aqueous extract in Plasmodium falciparum. Folia Medica Indonesiana 48 (3): 90-95. [Indonesian]

Madhurima P, Kuppast IJ, Mankani KL. 2012. A review on Amorphophallus paeoniifolius. Intl J Adv Sci Res Technol 2 (2): 99 111.

Mariappan N, Krishnakumar S, Kumar SR, Surendar KK. 2014 Caesalpinia sappan L: Comprehensive review on seed source variation and storability. Plant Gene Trait 5 (2): 11-21.

Mulyati, Djufri, Supriatno. 2017. Analysis vegetation of shade corpse flower (Amorphophallus paeoniifolius (Dennst.) Nicholson) in Padang Tiji sub-district of Pidie District. Jurnal Ilmiah Mahasiswa Fakultas Keguruan dan Ilmu Pendidikan Unsyiah 2 (1): 98-105. [Indonesian]

Nikmah N, Jumari, Wiryani E. 2016. Struktur komposisi tumbuhan bawah tegakan jati di kebun benih klon (kbk) padangan bojonegoro. Jurnal Biologi 5 (1): 30-38. \{indonesian]

Nurlaila A, Karyaningsih I, Herlina N. 2018. Diversification of forest food plants on agroforestry system in Kuningan District. J Environ 1: 1215.
Putri I, Hintono, A, Susanti, S. 2018. Optimization of Elephant Foot Yam (Amorphophallus paeoniifolius) extract syrup formula as a nutritive antioxidant drink. Int J Sustain Agric Res 5 (1): 1-9.

Ravi V, Ravindran CS, Suja G, George J, Nedunchezhiyan M, Byju G, Naskar SK. 2011. Crop physiology of elephant foot yam [Amorphophallus paeoniifolius (Dennst. Nicolson)]. Adv Hort Sci 25 (1): 51-63.

Romand-Monnier F. 2013. Amorphophallus paeoniifolius. The IUCN Red List of Threatened Species 2013. DOI: 10.2305/IUCN.UK.20132.RLTS. T44393336A44531586.en.

Santosa E, Lian CL, Sugiyama N, Misra RS, Boonkorkaew P, Thanomchit K. 2017. Population structure of elephant foot yams (Amorphophallus paeoniifolius (Dennst.) Nicolson) in Asia. PLoS ONE 12 (6): e0180000. DOI: 10.1371/journal.pone.0180000.

Santosa E, Susila AD, Lontoh AP, Noguchi A, Takahat K, Sugiyama N. 2015. NPK fertilizers for elephant foot yam (Amorphophallus paeoniifolius (Dennst.) Nicolson) intercropped with coffee trees. J Agron Indonesia 43 (3): 257-263. [Indonesian]

Singh A, Wadhwa N. 2014. A review on multiple potential of aroid: Amorphophallus paeoniifolius. Int J Pharmaceut Sci Rev Res 24 (1): 55-60.

Singh S, Singh R, Jha AB, Misra AN, Sharma P. 2017. Amorphophallus paeoniifolius corm: A potential source of peroxidase for wide applications, Int J Food Prop 20 (11): 2658-2664

Sugiyama N, Santosa E. 2008. Edible Amorphophallus in Indonesia: Potential Crops in Agroforestry. Gadjah Mada University Press, Yogyakarta.

Trimanto, Hapsari L. 2016. Botanical survey in thirteen montane forests of Bawean Island Nature Reserve, East Java Indonesia: Flora diversity, conservation status, and bioprospecting. Biodiversitas 17 (2): $832-846$

Yob NJ, Jofrry SM, Meor MM, Affandi M, Teh LK, Salleh MZ, Zakaria ZA. 2011. Zingiber zerumbet (L.) Smith: A review of its ethnomedicinal, chemical, and pharmacological uses. Evid Based Compl Altern Med 2011: 543216. DOI: 10.1155/2011/543216.

Yuzammi, Kurniawan A, Asih, NPS, Erlinawati I, Hetterscheld W. 2017. The Amorphophallus of Indonesia. Center for Plant Conservation Botanic Gardens, Indonesian Institute of Sciences, Bogor. 